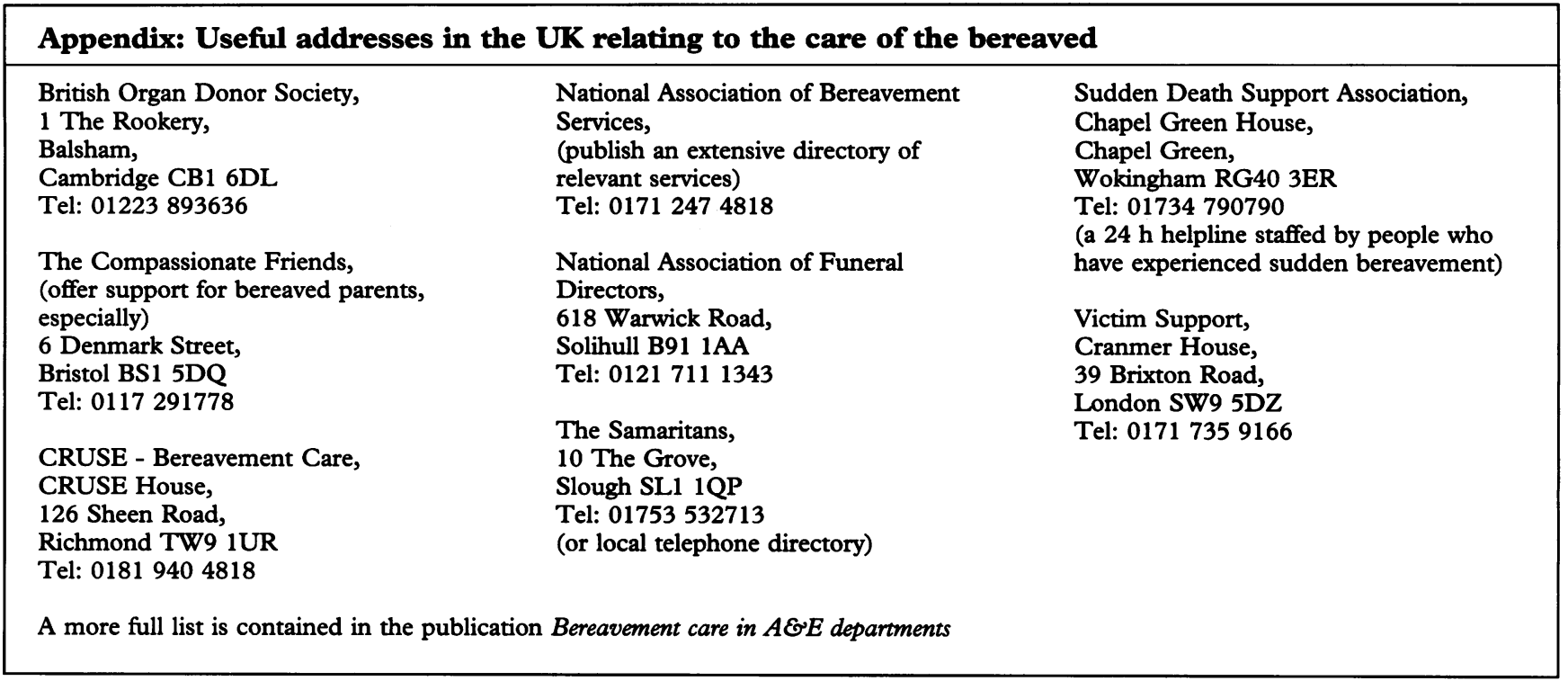

\title{
Medical Anniversary CAMILLO GOLGI, 7 JULY 1844
}

Camillo Golgi (1844-1926) was born in the Alpine village of Conteno in Italy, son of a general practitioner. He studied medicine in Pavia, qualifying (1865) with a thesis on mental disease. He practised as a country pathologist but returned to Pavia as professor of histology (1875). Golgi described the perivascular spaces of the brain and the endothelial origin of psammomas. He introduced a silver chromate stain for nerve cells, distinguishing motor from sensory cells, and he first described the intracellular organelles now known as the Golgi apparatus (1858). He shared the Nobel Prize with Cajal (1906). -DG fames 